\title{
USING QUESTION GENERATING TECHNIQUE IN TEACHING READING COMPREHENSION FOR THE THIRD SEMESTER STUDENTS AT ENGLISH STUDY PROGRAM OF MUHAMMADIYAH UNIVERSITY OF BENGKULU
}

\author{
Washlurachim Safitri \\ Englis h Department Study Program of Universitas Muhammadiyah Bengkulu \\ washlurachimsafitri@yahoo.co.id
}

\begin{abstract}
:
The objective of this research was to find out Using Question Generating Technique Toward Students Reading Comprehension At The Third Semester Students At English Study Program Of Muhammadiyah University Of Bengkulu. The design of this research was Quasi experimental research. The subject of this research is students at the third semester of English study program. They were A class that consist of 20 students and D class that consist of 20 students. In collecting data, the researcher used some steps; firstly the students were given a pre-test before the researcher applied Question Generating Technique. Then, the researcher did the treatment for three meetings to the experimental class, after that the researcher did post test to both classes. The last, the researcher analyzed the result of reading test by using criteria for the assessment. The final step was the researcher discussed and concluded the data. The result of this research showed that the tobt was 4,880 . Whereas, the degree of freedom of post-test is 68 , means that the ttable was 2.021. Based on the scores gained, it shows that tobt is higher than ttable $(9,911>4,880)$. There is a significant difference between the posttest mean of the experimental and control class. The result also showed that the students' comprehension in reading was significantly. In conclusion, the Question Generating Technique had been successfully gave positive effect to the students' reading comprehension particularly in reading subject in English study program of University Muhammadiyah of Bengkulu.
\end{abstract}

Key Words : Question Generating Technique, Reading comprehension,

\section{INTRODUCTION}

Reading is the process of looking at a series of written symbols and getting meaning from the passage. Reading is a skill that needed in education. From elementary to college cannot be separated from reading comprehension. Humans are required to have the high reading activity. It is because reading is a complex and complicated process (Nurhadi, 2008, p.14). Complicated in reading skill can mean as external and internal factor that interconnected each other that support reading comprehension.

Reading comprehension can be defined as the level of understanding of a text/message. This understanding comes from the interaction between the words that are written and how trigger knowledge outside the text/message. Reading activities from many information sources will give knowledge to every people. The delivery of written information on the modern century 
is a thing that can not be left. In daily life requires reading skill because reading comprehension is needed to understand the signs and rules ranging from simple in the environment.

The purpose of reading is to get good and bad information from both electronic media and print media. Every day the information is presented in the form knowledge, facts, research findings, coverage of an event, and other so which is presented through print media or electronic media. Even to communicate with another person in long distance also used short messange service(sms), facebook, email, and other forms that require high literacy to be able to understand the message and respond to the message given by an informer. In human life will not escape from the communication process.

Based on preliminary research that have done by researcher in students reading comprehension at the third semester, the researcher found that the students often faced obstacles. Most of them are difficult in understanding the passage, difficult in concluding the point of the passage, and also the students lack vocabulary. One of the method that can be selected to enhance the ability to read is with the use of the questions generating technique.

According to the Ann B. and Thomas L (2008, p. 56) state that Question Generation is a technique that assists students with their comprehension of text. Students learn to formulate and respond to questions about situations, facts, and ideas while engaged in understanding a text.

Question Generation helps to improve critical and creative thinking skills as students learn to ask questions about an assigned text. This technique encourages students to develop lifelong learning skills. Question Generation is flexible and may be tailored to fit various types of information, and different skill-levels. Students may use this technique with the help of a facilitator or they may generate questions on their own (Wyse, 2004)

One of the primary benefits of modeling the generating questions technique is that students will be able to witness a display of intellectual reasoning. As they hear the instructor discussing the questions she selected and why she deemed the questions to be important, the students get to experience a higher level of thinking than that to which they may have been previously exposed.

To improve students' reading comprehension, teachers should use a variety of learning methods in reading lesson. Here, the role of the teacher in choosing a technique of reading appropriate to achieve the purpose of reading is very necessary. The expertise of teachers in choosing a technique of reading process affect the students' reading comprehension. One of 
technique to enhance student's reading comprehension by using questions generating technique. Questions generating technique involves requiring students to read a specific assignment, create questions designed to elicit important information from the passage, and answer their questions. In reading sometimes found constraints to understand the reading passage.

Based on the explanation above, the researcher want to solve the problems in reading comprehension at the third semester students of english study program of University Muhammadiyah of Bengkulu.

The problem of this research is "Did the using of question generating technique could improve in teaching reading comprehension for the third semester students of English study program of Muhammadiyah University of Bengkulu?".

\section{RESEARCH METHOD}

The design of this research is quasi experimental research because aim to reveale the effect of using question generating technique toward students reading comprehension at the third semester students of English Study Program of University Muhammadiyah of Bengkulu. Ary (2010,p.316) stated that quasi-experimental designs are similar to randomized experimental designs in that they involve manipulation of an independent variable but differ in that subjects are not randomly assigne to treatment groups.

It involves two classes. Both classes are given the same pre-test and post-test. The experimental class received a treatment by applying using question generating technique, while the control class was taught by ordinary way.

The Design of the Experiment

\begin{tabular}{|c|c|c|c|}
\hline Classes & $\begin{array}{c}\text { Pre- } \\
\text { test }\end{array}$ & $\begin{array}{c}\text { Independent } \\
\text { variable }\end{array}$ & Post-test \\
\hline Experimental & $\mathrm{Y}_{1}$ & $\mathrm{X}$ & $\mathrm{Y}_{2}$ \\
\hline Control & $\mathrm{Y}_{1}$ & - & $\mathrm{Y}_{2}$ \\
\hline
\end{tabular}

$\mathrm{Y}_{1}$ : Pre-test experimental and control group.

$\mathrm{X}$ :using question generating technique is applied in the experimental group.

- $\quad$ :using question generating technique is not applied in the experimental group.

$\mathrm{Y}_{2}$ : Post-test experimental and control group.

The population of the this research. Ary (2010) stated that population is all members of any well-defined class of people, events, or objects. The population of this research is all the 
third semester students of English Study Program at University Muhammadiyah of Bengkulu. Which consist of four classes, they are A, B, C, and D. The total number of the subject in this research are 104 students, as can be seen in the table below:

Table. Population

\begin{tabular}{|c|c|}
\hline Class & Total of Students \\
\hline A & 28 \\
\hline B & 28 \\
\hline C & 28 \\
\hline D & 20 \\
\hline Total Population & 104 Students \\
\hline
\end{tabular}

(Source : The attendance list of the third semester students)

Fraenkel and Wallen (2008,p. 101) sample is a part of population. Ary (2010,p.156) stated that sample is the small group that is observed. The researcher take the sampling purposively and the samples take $25 \%$ of the population. So, they were 30 students. III C class control and III A as an experiment class. The researcher choosed III A class as an experiment class because based on preliminary, some students had low speaking comprehension at the class such as Most of them are difficult in understanding the passage, difficult in concluding the point of the passage, and also the students lack vocabulary.

The instrument of this research were : 1). Video recorder which is used to record the activities in teaching reading English in the class, and 2). Analytic scoring rubric which is used to score rubric to give score for the students to know.

This research used two groups which teach in the same period of time and using the same material the difference is on the use of kind of treatment. Before the researcher did the treatments, the researcher gave pre-test for experimental and control class that have similar background as samples to know the comprehension in reading. In the treatment session the researcher did the treatment for three meetings to the experimental groups. There were different treatments between two groups.

1. After the score of pretest was find, experimental group gave some treatments through using question generating technique which procedures:

\section{Treatment I}

a. The researcher explained that in this lesson students generated questions to help them understand a News article. 
b. Pass out printed copies of the News article about SCTV- travelers were killed was struck by a train

c. Explain that generating questions improves understanding.

d. Briefly discuss what students think the article is about.

e. Ask students to generate their own questions. Prompt them to Ask questions that are literal. (Who? What? When?)

f. Ask questions that require drawing a conclusion or making an inference. (Why? How?)

g. Evaluate whether the question was a good question and answer the question.

\section{Evaluation Treatment I}

Based on the result of treatment 1, it showed that the students' reading comprehension at the third semester of English Study Program of Muhammadiyah University of Bengkulu still need much improvement. So the next treatment was needed in order to improve the students' reading comprehension.

\section{Treatment II}

a. Similar to treatment I, The researcher Pass out printed copies of the News article about different topic: The death toll is reduced

b. Briefly discuss what students think the article is about.

c. Ask students to generate their own questions. Prompt them to Ask questions that are literal. (Who? What? When?)

d. Ask questions that require drawing a conclusion or making an inference. (Why? How?)

e. Evaluate whether the question is a good question and answer the question.

\section{Evaluation Treatment II}

Based on the result of treatment II, it showed that the students' reading comprehension at the third semester of English Study Program of Muhammadiyah University of Bengkulu not maximal yet. There were some aspects that need to be improve. so the next treatment was needed in order to improve the students' reading comprehension.

\section{Treatment III}

a. In the last treatment, Pass out printed copies of the News article about CNN TV-Tokyo, Desneylan Reopens After Quake

b. Ask students to generate their own questions. Prompt them to Ask questions that are literal. (Who? What? When?)

c. Ask questions that require drawing a conclusion or making an inference. (Why? How?)

d. Evaluate whether the question is a good question and answer the question.

\section{Evaluation Treatment III}

Based on the result of treatment III, it showed that the students' reading comprehension at the third semester of English Study Program of Muhammadiyah University of Bengkulu was good. So the next treatment was not needed anymore. 


\section{The Control Class}

The steps on the control class are:

a. The researcher enters the classroom and gives greeting, before starting to study.

b. The researcher explains the technique and the rule of activity that would be apply in the class.

c. The researcher asked student to read and understand about text that had read by them.

d. The researcher gave question "what are their opinion about text that had read by them?.

e. The researcher conclude about text together the students.

\section{Post test gave for both groups.}

From post-test score, the data would analize to find on the the effect of using question generating technique toward students reading comprehension In collecting data the researcher would be use some following steps :

The researcher gave reading assignment. Pre-test give to the class before the treatments to see how the students' reading comprehension before the use of question generating technique. Furthermore, the experimental group receive a treatment that is question generating technique, yet the control group learn in the conventional way or do not get the treatment. After receiving the treatment, the experimental and control groups gave the post-test to see how the students' reading comprehension particulary in the used of question generating technique.

\begin{tabular}{|c|l|}
\multicolumn{1}{c}{ Table of Level } \\
\begin{tabular}{|c|} 
Achie vem \\
ent le vel
\end{tabular} & \multicolumn{1}{c|}{ Le vel descriptor } \\
\hline 0 & The student does not reach a standard described by any of the descriptors. \\
\hline $1-2$ & $\begin{array}{l}\text { The student: } \\
\square \square \text { makes a limited attempt to identify basic facts, main ideas and supporting details in simple } \\
\text { short written texts with familiar language } \\
\square \square \text { has difficulty recognizing basic aspects of format and style, and author's purpose for writing } \\
\square \square \text { makes a limited attempt to engage with the text by identifying ideas, opinions and attitudes in } \\
\text { the text; makes minimal connections with own experiences and attitudes } \\
\square \square \text { shows limited understanding of the content of the text as a whole. }\end{array}$ \\
\hline $3-4$ & $\begin{array}{l}\text { The student: } \\
\square \square \text { identifies some basic facts, main ideas and supporting details in simple short written texts with } \\
\text { familiar language } \\
\square \square \text { recognizes some basic aspects of format and style, and author's purpose for writing } \\
\square \square \text { occasionally engages with the text by identify ing ideas, opinions and attitudes in the text!and } \\
\text { making some connections with own experiences and attitudes } \\
\square \square \text { shows some understanding of the content of the text as a whole. }\end{array}$ \\
\hline $5-6$ & $\begin{array}{l}\text { The student: } \\
\square \square \text { identifies most basic facts, main ideas and supporting details in simple short written texts with } \\
\text { familiar language } \\
\square \square \text { recognizes most basic aspects of format and style, and author's purpose for writing } \\
\square \square \text { usually engages with the text by identify ing ideas, opinions and attitudes in the text!and } \\
\text { making ample connections with own experiences and attitudes } \\
\square \square \text { shows considerable understanding of the content of the text as a whole. }\end{array}$ \\
\hline $7-8$ & $\begin{array}{l}\text { The student: } \\
\square \square \text { identifies basic facts, more complex ideas and supporting details in simple short written texts } \\
\text { with familiar language } \\
\square \square \text { recognizes basic aspects of format and style, and author's purpose for writing } \\
\square \square \text { engages with the text by identifying ideas, opinions and attitudes in the text and making } \\
\text { substantial connections with own experiences and attitudes } \\
\square \square \text { shows thorough understanding of the content of the text as a whole. }\end{array}$ \\
\hline 5
\end{tabular}


The total score then interpreted by using the interpretation level on table of level Table of Level interpretation

\begin{tabular}{|c|c|}
\hline Range of score & Descriptor \\
\hline $7-8$ & Excellent \\
\hline $5-6$ & Very Good \\
\hline $3-4$ & Good \\
\hline $1-2$ & Fair \\
\hline 0 & Very poor \\
\hline
\end{tabular}

The scores of the test gave the data to be analysis. Since this research is basically intend to investigate the effect of using question generating technique toward students reading comprehension at the third semester students of English study program of University Muhammadiyah of Bengkulu. The data is obtain from the research analyze by using Microsoft Office Excel 2007, SPSS 16.0 for Windows Evaluation Version in which the formula of Independent-Sample t Test.

The indicator of success is considered successful if at least $70 \%$ of students achieve good or very good ability level in reading comprehension. Also, the indicator of the score which students have to achieve was 15.

\section{FINDING AND DISCUSSIONS}

The pre-test resulted the following output. The researcher gave the pretest to both groups before giving the treatment to make sure that the experimental and the control class had the equal ability in reading comprehension. The result of pre test can be described as follow : 
Table Pre Test Score Distribution

\begin{tabular}{|c|c|c|c|c|}
\hline \multirow{2}{*}{$\begin{array}{l}\text { Number } \\
\text { of subject }\end{array}$} & \multicolumn{2}{|c|}{ Experiment Group } & \multicolumn{2}{|c|}{ Control Group } \\
\hline & $\mathbf{X 1}$ & $\bar{X} 1^{2}$ & $\mathrm{X} 1$ & $\mathrm{X} \mathbf{1}^{2}$ \\
\hline 1 & 65 & 4225 & 60 & 2500 \\
\hline 2 & 60 & 3600 & 55 & 2500 \\
\hline 3 & 60 & 3600 & 50 & 2025 \\
\hline 4 & 55 & 3025 & 50 & 1600 \\
\hline 5 & 55 & 3025 & 50 & 1225 \\
\hline 6 & 50 & 2500 & 50 & 4225 \\
\hline 7 & 50 & 2500 & 50 & 3025 \\
\hline 8 & 50 & 2500 & 45 & 3025 \\
\hline 9 & 45 & 2025 & 45 & 2500 \\
\hline 10 & 45 & 2025 & 45 & 2025 \\
\hline 11 & 45 & 2025 & 45 & 2025 \\
\hline 12 & 45 & 2025 & 45 & 2500 \\
\hline 13 & 45 & 2025 & 40 & 2025 \\
\hline 14 & 40 & 1600 & 40 & 3025 \\
\hline 15 & 40 & 1600 & 40 & 3600 \\
\hline 16 & 40 & 1600 & 40 & 3600 \\
\hline 17 & 40 & 1600 & 40 & 3025 \\
\hline 18 & 35 & 1225 & 35 & 2500 \\
\hline 19 & 35 & 1225 & 35 & 2025 \\
\hline 20 & 35 & 1225 & 35 & 2025 \\
\hline Score & 935 & 45175 & 895 & 51000 \\
\hline Average & 46,75 & & 44,75 & \\
\hline
\end{tabular}

From the table above, it can be seen that the total score of the students' achievement in the experimental group was 935 and total score of the students' achievement in control group was 895 . The mean of the experimental group is 46,75 , while the mean of control group is 44,75 . It can be assumed that the means of two classes is not significantly different. The t-count was calculated by using SPSS 16. You can see the table bellow. 


\begin{tabular}{|c|c|c|c|c|c|}
\hline & kelas & $\mathrm{N}$ & Mean & Std. Deviation & Std. Errar Mean \\
\hline \multirow[t]{2}{*}{ Ljian } & D & 20 & 46.75 & 9.430 & 1.886 \\
\hline & A & 20 & 44.79 & 9.126 & 1.298 \\
\hline
\end{tabular}

The Post Test Result . After giving the treatment for a period of experimentation, the post test was administered. The treatment was given for 3 meeting by the researcher to the students of experimental and control group. The post test result is showed in table below :

Post Test Score Distribution

\begin{tabular}{|c|c|c|c|c|}
\hline \multirow{2}{*}{$\begin{array}{l}\text { Number } \\
\text { of subject }\end{array}$} & \multicolumn{2}{|c|}{ Experiment Group } & \multicolumn{2}{|r|}{ Control Group } \\
\hline & $\mathbf{X 1}$ & $X 1^{2}$ & $\mathrm{X} 1$ & $X 1^{2}$ \\
\hline 1 & 90 & 8100 & 80 & 6400 \\
\hline 2 & 90 & 8100 & 70 & 4900 \\
\hline 3 & 90 & 8100 & 70 & 4900 \\
\hline 4 & 80 & 6400 & 60 & 3600 \\
\hline 5 & 80 & 6400 & 60 & 3600 \\
\hline 6 & 80 & 6400 & 60 & 3600 \\
\hline 7 & 75 & 5625 & 60 & 3600 \\
\hline 8 & 75 & 5625 & 60 & 3600 \\
\hline 9 & 70 & 4900 & 60 & 3600 \\
\hline 10 & 70 & 4900 & 60 & 3600 \\
\hline 11 & 70 & 4900 & 55 & 3025 \\
\hline 12 & 70 & 4900 & 55 & 3025 \\
\hline 13 & 70 & 4900 & 55 & 3025 \\
\hline 14 & 65 & 3625 & 55 & 3025 \\
\hline 15 & 65 & 3625 & 55 & 3025 \\
\hline 16 & 65 & 3625 & 55 & 3025 \\
\hline 17 & 65 & 3625 & 55 & 3025 \\
\hline 18 & 60 & 3600 & 55 & 3025 \\
\hline 19 & 60 & 3600 & 55 & 3025 \\
\hline 20 & 60 & 3600 & 50 & 2500 \\
\hline Score & 1450 & 104550 & 1185 & 71125 \\
\hline Average & 72,5 & & 59,25 & \\
\hline
\end{tabular}


From the table above, it can be seen that the total score of the students' achievement in the experimental group was 1450 and total score of the students' achievement in control group was 1185 . The mean of the experimental group is 72,5, while the mean of control group is 59,25. The t-count was calculated by using SPSS 16. This follow :

\begin{tabular}{|rl|r|r|r|r|}
\hline & kelas & N & \multicolumn{1}{|c|}{ Mean } & Std. Deviation & Std. Error Mean \\
\hline Ujian & D & 20 & 72.50 & 10.308 & 2.062 \\
& A & 20 & 59.25 & 7.440 & 1.476 \\
\hline
\end{tabular}

Based on the test calculation, the $\mathrm{t}$ obtained is 4.880 while in the table value is 2,021 . So, $t$ obtained is bigger than t table $(4.880>2,021)$. The researcher concluded that there was a significant different between the mean score of the post test. In other word, there was a significant positive effect of the question generating technique to students' reading comprehension.

\section{The Analysis of Pre Test and Post Test Result}

In table of pre test distribution, the mean score of experimental classwas 44,2 and the mean score class was 42,8 . The t-test of pre test score was 0,68 .

In the table of post test distribution, the mean score of the experimental class was 72,5 and the mean score of control class was 59,25. The t-test of post test was 4,880. There was a significant difference in the Pre test and Post test score between the experimental class and control class.

\section{DISCUSSION}

In analyzing pre-test and post-test result, the score of both test were compared to see whether the treatment in experimental class give the effect or not. The following table may help the clarification and contains the comparative result of pre-test and post-test in experimental class and control class. 


\section{Comparison pre-test and post-test result}
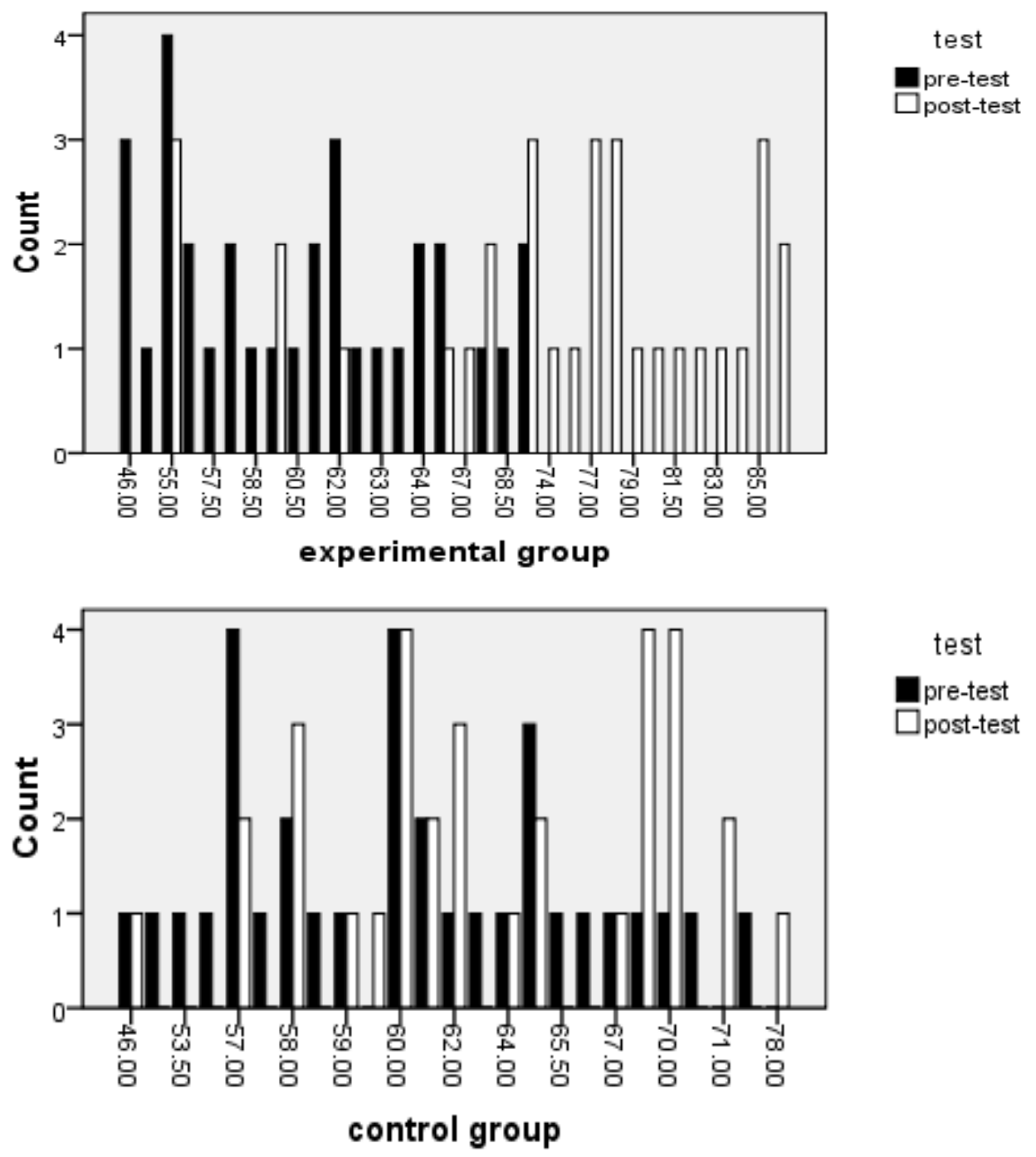

test

Dre-test

$\square$ post-test

The statistical computations on pre test scores of the experimental and control group using SPSS 16 for windows showed that the distribution of the experimental and control class's scores on pre test was normal. The variances of the two group's pre test scores are equal. It was found that test count $(0,68)$ and $t$-table $(2,021)$. It means that $t$-count was smaller than t-table. Based on the explanation, there was no significant difference between two samples or two classes. It means that two group were equal ability, and the researcher could be continued.

The statistical computations on the pre test scores of the experimental and control group using SPSS 16 for windows showed that it was found that test count $(4,880)$ and t-table $(2,021)$. Based on the data above, we can concluded that there was significant different of 
post testresult between both control class and experimental class. We could see the improvement made by the students after using question generating technique in increasing students' reading comprehension. Then, we also found that was significant effect of question generating technique in increasing students reading skill. It can looked at the highest score of experimental class achievement than the control class which were not using the question generating technique.

The result of students' reading comprehension in experimental group which implemented with question generating technique of this research showed that there was significant positive effect. It was in line with Berry (1997,p. 44) There must be question on the text, this essential. The questions are to help the pupils understanding every detail on the passage, for example, the passage is about "hide and seek". It means that the questions on the passage are able to facilitate the pupils understanding of the passage.

Through question technique, the students' reading comprehension was improve. It support by Sheng (2003,p.61) reading comprehension questions measure student's ability to read with understanding, insight and discrimination. This type of question explores the ability to analyze a written passage from several perspectives, including student's ability to recognize both explicitly stated elements in the passage and assumptions underlying statements or arguments.

There was found that significant effect of implementation question generating technique in improve students' experimental class achievement than the control class which were not using the question generating technique. It means that the students were helped with this technique. Question Generation helps to improve critical and creative thinking skills as students learn to ask questions about an assigned text. This technique encourages students to develop life-long learning skills. Question Generation is flexible and may be tailored to fit various types of information, and different skill-levels. Students may use this technique with the help of a facilitator or they may generate questions on their own (Wyse, 2004).

It was also supported by the Ann B. and Thomas L (2008,p. 56) state that Question Generation is a technique that assists students with their comprehension of text. Students learn to formulate and respond to questions about situations, facts, and ideas while engaged in understanding a text. 


\section{CONCLUSION AND SUGGESTION}

\section{Conclusion}

Based on the result in the previous chapter, the researcher can conclud that reading comprehension of the third semester of English study program is still low. The students' face difficulties in comprehend the meaning of the text. . They could not understand every detail on the passage of the text. It can be seen at the data value score from the lecturer concerned. After the students is given a question generating technique, they are become active, focuss reading and the learning process is become more enjoy.

And based on the test calculation, the t obtained is 4,880 while in the $t$ table value is 2,021 . So, $\mathrm{t}$ obtained is bigger than $\mathrm{t}$ table $(4,880>2,021)$. The researcher concluded that there is a significant different between the mean score of post test. In other word, there is significant positive effect of the question generating technique to students' reading comprehension. It indicated that using question generating technique can be increasing students reading comprehension skill. So, it can be conclude that the questions generating technique can be applied in third semester specially for reading comprehention.

\section{Suggestion}

Based on conclusion above, the researcher suggests that:

1. The question generating technique can be implemented by lecturers in teaching reading comprehension because it has give positive effect to increase students' reading comprehension.

2. The question generating technique can give motivation to the students in learning reading comprehension.

3. The further research can use the question generating technique in order to improve order skill such speaking.

4. The further research can implement the Question Generating Technique to the different subject. 


\section{References}

Ann B. And Thomas, L. (2008). Decision Making of Question. International journal volume 1, hal. 83-97.

Ary, D. (2010). Introduction to Research and Education. Canada : wadsworth cengage lerning.

Berry, James. (1997) Level of Question. Retrieved from http//www.sc4.edu/documents/studyskills/h7levelsreadingcomp.doc. accessed on 17 februari 2015.

Frankel J.P and Wallen N.E. (2008). How To Design And Evaluate Research In Education. New York : McGraw-Hill Companies Inc

Nurhadi. (2008). Proses Membaca dan memahami penelitian Kuantitatif. Jakarta. Reneka. Cipta.

Sheng, H J. (2003). A cognitif Model for teaching reading comprehension in forum english teaching

Wyse. (2004). http://faculty.washington.edu/krumme/guides/bloom.html 